\title{
COSMOPOLITISMO CIENTÍFICO E CULTURAS LOCAIS: percepções dos avanços da ciência por lideranças religiosas no recôncavo baiano
}

\author{
Amilcar Baiardi* \\ Fabihana Souza Mendes ** \\ Wellington Gil Rodrigues ${ }^{* * *}$
}

\begin{abstract}
Os avanços da ciência, no campo das medicinas e da biologia, são percebidos de maneira diversa, a depender da cultura, dos valores, da religiosidade etc. No Recôncavo da Bahia, Brasil, território que, no período colonial, foi o mais importante centro comercial da província e seu maior produtor de cana de açúcar e de algodão, isso se dá emblematicamente. Nessa região, grupos populacionais, formados por descendentes de produtores rurais e agregados, com etnia branca, e por descendentes de escravos, com etnia negra, vêm, ao longo dos séculos, metamorfoseando e consolidando crenças. Desses processos resultou uma grande diversidade de crenças: de gênese cristã, catolicismo e protestantismo, de origem africana, Ilê Axé Ogunjá e Candomblé de essência nagô e Malé, de influência islâmica, e com raízes mistas, envolvendo catolicismo e religiões africanas, tipo a seita da "Boa Morte" e a Umbanda. Esse amplo espectro de religiões que convivem sem conflitos manifesta reações diferentes a práticas e condutas da ciência contemporânea. Questões como a modificação genética, o uso de células-tronco, a clonagem etc. são vistas de forma diferente, com tolerância ou resistência por parte desses sistemas de crenças. O presente trabalho se propõe a fazer uma sistematização de reações de líderes religiosos a alguns símbolos da ciência moderna.

PaLAvras-chave: Ciência e religião. Religiões no Recôncavo da Bahia-Brasil. Percepções da ciência por líderes religiosos.
\end{abstract}

\section{INTRODUÇÃO}

O presente trabalho se propõe a sistematizar os elementos simbólicos presentes nas religiões e suas implicações para a aceitação plena dos cânones da ciência moderna na Região do Recôncavo Baiano. Ele resulta de uma pesquisa empírica realizada na cidade de Cachoeira e no seu entorno. O Recôncavo da Bahia é conhecido nacional e internacionalmente por seu patrimônio histórico e cultural, marcado pelo passado colonial e escravista, que se revela na composição étnica de sua população, na arquitetura barroca, na religiosidade e na cultura popular. Éreconhecido como o lugar de origem do samba e do candomblé.

O samba de roda, por exemplo, reconhecido pela UNESCO em 2005 como Obra Prima do

* Professor permanente do Programa de Pós Graduação em Ensino, Filosofia e História da Ciência (UFBA/UEFS) e da pós-graduação da Universidade Católica do Salvador.

Rua: Barão de Geremoabo s/n. Cep: 40170-115. Salvador - Bahia - Brasil. amilcarbaiardi@uol.com.br

* * Doutoranda do Programa dePós Graduação em Difusão doConhecimento (UFBA, UNEB, IFBA). fabihanamendes@gmail.com

* * * Doutorando do Programa de Pós-Graduação em Ensino, Filosofia e História da Ciência (PPGEFHC-UFBA/ UEFS).wellgil2000@hotmail.com
Patrimônio Oral e Imaterial da Humanidade, tem origens por volta de 1860, nessa região. Esse território foi historicamente chamado de Recôncavo pelos colonizadores portugueses, para designar o arco ao redor da Baía de Todos os Santos. Consolida-se, desde então, a denominação de Recôncavo da Bahia. Segundo a historiadora Katia Mattoso (1992, p.51), recôncavo significa "fundo da baía". O Recôncavo Baiano, porém, abrange terras adjacentes, ilhas e ilhotas, indo além das praias por vales, várzeas e planaltos próximos ao mar, que se estendem por quase trezentos quilômetros de águas tranquilas e tépidas.

No território do Recôncavo Baiano localizase a cidade de Cachoeira, que pertence ao município do mesmo nome, a qual reúne, mais que qualquer outra, a herança do período colonial escravista. A cidade de Cachoeira e seu entorno, que, pela sua história e seu papel no período colonial, chegou a ser um polo de produção e exportação de açúcar em decorrência da navegabilidade do Rio Paraguaçu, desempenha também um papel especial nas rotas de comércio em direção ao hinterland, o Sertão do São Francisco e Minas Gerais, e em 
direção à Europa, constituindo-se em um entreposto do que se produzia para exportar e do que se importava da metrópole. Essas atividades econômicas tinham como principal força de trabalho escravos africanos, constituindo aquilo que ficou conhecido como escravismo colonial, para se distinguir do escravismo clássico, que ocorreu na antiguidade greco-romana.

A região era pródiga em termos de recursos naturais, inclusive pastagens, o que ensejou várias atividades produtivo-primárias e também produtivo-secundárias, como fabricação de açúcar e de charutos. O crescimento da região a partir do comércio, bem como da agroexportação e da agricultura mercantil de subsistência, irá permitir uma permanente expansão econômica e uma prosperidade que apresenta descontinuidade somente bem depois no início do século XIX. Nela ocorreram os processos econômicos mais significativos e dinâmicos ainda nos séculos XVI, XVII e XVIII. A demanda e os preços animadores do açúcar e do fumo no comércio exterior explicavam o dinamismo.

Ademais, o Recôncavo, particularmente em Cachoeira, era palco de movimentação política em prol da cidadania, criando a semente da insatisfação com a condição de Colônia para o Brasil, o que viria a se materializar na resistência à presença portuguesa no Brasil e na Bahia e nos atos próindependência das reuniões de 14 de junho na Vila de Santo Amaro e 25 de junho na Vila de Cachoeira, precursores que foram do sete de setembro, segundo Tavares (2005).

Essas lavouras e seu beneficiamento, entretanto, dependiam não só da mão de obra escrava, mas também de homens livres, contratados mediante diversas formas de pagamento, inclusive salários. O impulso econômico dessas atividades ensejou outras subsidiárias no entorno do engenho, como a pecuária e as lavouras de café, algodão e mandioca, gerando relações sociais mais complexas que não se reduziam àquelas entre senhores e escravos. Por essa razão, a população de Cachoeira se constituía e expandia não só determinada pela produção de cana-de-açúcar e do fumo, atividades primárias, mas também influenciada pelo beneficiamento do fumo, pela fabricação de charutos, pelo transporte, armazenamento e comercialização dos derivados da folha de fumo. A importância econômica de Cachoeira fez com que, no município, proliferassem serviços mais qualificados como os bancários e cartoriais. Com o aumento da produção fumageira visando à exportação, grandes fábricas foram instaladas na região por empresários europeus, interessados no fumo aromático para a produção de charutos, o que marcou o fim da centralidade da agroindústria açucareira na região. Essa gênese econômica repercutiu na composição social e étnica, visto que a demanda por força de trabalho se dava por várias profissões e vários níveis de capacitação (Nardi, 1987).

Não obstante esses avanços, a principal atividade econômica até o século XIX continuava sendo a produção de açúcar, que integrava a plantation, monocultura de cana, com os engenhos, produtores de açúcar. Referencial de riqueza na colônia, a agroindústria açucareira começaria a declinar em meados do século XIX, quando os engenhos entrariam em processo de estagnação, retirando dinamismo da economia colonial e de sua principal atividade, a produção de açúcar. A crise é, segundo alguns autores, decorrência da concorrência do açúcar produzido nas Antilhas por produtores europeus e tem também como causa problemas de reposição da força de trabalho escrava que se tornou escassa após a proibição do tráfico (Baiardi et al, 2007).

O início da crise é datado por alguns em 1830, quando o açúcar perde a liderança de exportações da recente nação brasileira. A origem da crise, em geral associada com a concorrência do açúcar produzido nas Antilhas, residiria também, segundo Cunha (2004), na incapacidade da classe de senhores de engenho se adaptar à nova realidade, tendo de começar a remunerar o trabalho, mesmo antes da abolição, em decorrência da escassez de escravos, demandados pela expansão cafeeira em São Paulo e Rio de janeiro. Os senhores de engenho também resistiam em proceder a alterações nos processos de produção agrícola e agroindustrial, preferindo técnicas rotineiras às inovações tecnológicas que, de acordo com Jancsó 
Amilcar Baiardi, Fabihana Souza Mendes, Wellington Gil Rodrigues

(1996), começavam a aparecer. Essa economia era conceituada por alguns historiadores como pré-capitalista, por estar associada à grande propriedade da terra, outorgada pelo poder colonial a senhores da nobreza, e, por outros, como plenamente capitalista, por estar vinculada ao capital mercantil e aos circuitos internacionais de acumulação.

Como a atividade comercial e o tráfico de escravos eram atividades muito afins, esse agrupamento social, que era o empresariado baiano, já presente nos séculos XVII, XVIII e XIX, somente adquire uma mentalidade mais próxima à da burguesa quando a Bahia começa a diversificar sua estrutura econômica a partir da segunda metade do século XIX. Nessa diversificação, as indústrias têxteis e fumageiras, bem como o comércio, aparecem como as melhores alternativas. Por razões de localização estratégica, Cachoeira beneficia-se com esses investimentos, constituindo-se, no fim do século XIX, em uma localidade que se destacava na economia do Recôncavo e da província. Isso se dava porque havia, segundo Baiardi et al. (2007), em Cachoeira, uma cultura de empreendedorismo e porque o Recôncavo começara a se beneficiar dos primeiros resultados das pesquisas e da difusão de conhecimentos decorrentes da criação do Imperial Instituto Baiano de Agricultura em 1874, os quais impactaram na diversificação das lavouras e no surgimento de indústrias processadoras de matéria-prima vegetal (Baiardi, 1999).

Já no século XIX, após um período de retração econômica, mais propriamente na década de 1860, novo impulso é dado à região e dele se beneficia Cachoeira mais que qualquer outra cidade. É o início do transporte ferroviário, que, para Cachoeira, teve um significado básico para sua evolução socioeconômica. A ferrovia consolida a posição da cidade como centro comercial no Recôncavo, que passava a dispor de um porto fluviomarinho, conectado a uma estrada de ferro a Central da Bahia - que ligava a cidade de Salvador à região Sudeste do Brasil, pois havia um ramal que se estendia de Cachoeira até a cidade de Feira de Santana.

É possível afirmar que, com o advento da produção tipicamente capitalista, tanto na produção rural como na urbana, onde se instalaram fábricas, consolida-se uma estratificação social. Nela, a classe dominante e os estratos médios que surgem com o desenvolvimento da burocracia estatal e serviços professavam o catolicismo e os ex-escravos, precariamente trabalhadores assalariados, professavam religiões afro-brasileiras com conteúdos de sincretismo visando a evitar perseguições. Cachoeira, portanto, abriga duas fortes heranças: a de vários empreendedores ligados a atividades produtivas, nas quais se destacava a figura do produtor de açúcar de origem ibérica, que era senhor de escravos, e a dos próprios escravos provenientes da África. Desses dois agrupamentos sociais vieram as raízes da religião católica e de religiões afro-brasileiras. Recentemente, sem uma causa convincente, Cachoeira passou a ser também palco de outras manifestações religiosas, principalmente vertentes do protestantismo, algumas delas tradicionais e com projetos educacionais, como a adventista, e outras com história de criação recente e sem qualquer projeto que não seja a catequese.

Dada essa presença de várias religióes convivendo sem aparentes conflitos em um território limitado, optou-se por tomar Cachoeira como proxy do Recôncavo e da Bahia, estado brasileiro que mais diversidade religiosa apresenta em um clima de grande tolerância, para avaliar a percepção das religiões em relação à ciência.

\section{CIÊNCIA, BIOÉTICA E RELIGIÃO}

Há diversos tipos possíveis de interações entre ciência e religião (Barbour, 2004). No entanto, parece que, geralmente, há uma predominância, ou pelo menos mais visibilidade de um tipo específico de relação entre essas duas matrizes explicativas do mundo.

As relações entre ciência e religião geralmente tendem a ser percebidas através de uma ótica dicotomizada, a partir da qual tendemos a construir nossa visão de mundo: os de princípios científicos de um lado e os religiosos, de outro. Os 
inúmeros avanços da ciência ajudaram a estabelecer a imagem do conhecimento científico como algo quase incontestável, o que provoca em muitos professores uma postura fechada em um cientificismo radical; outra ala responde com um fundamentalismo religioso, colocando em choque essas duas cosmovisões (Rodrigues; Motta, 2011, p.106).

As interações entre ciência e religião encontram, na bioética, um campo fértil para manifestações de divergências que vão se modificar em função de cada momento histórico particular, da região e da cultura na qual surgem e também da particularidade de cada religião, visto que elas reagem diferentemente aos desafios postos pelos avanços da ciência e suas implicações sobre questões que envolvem a religiosidade.

Para Evans (2010), a emergência do debate público sobre a bioética surgiu a partir das inúmeras possibilidades tecnológicas que despontam na década de 1960, as quais alarmaram muitos cientistas que passaram a se questionar sobre o que deveria ser feito com essas novas tecnologias. $\mathrm{Na}$ conferência de Londres, no início da década de 1960, muitos cientistas se reuniram para discutir sobre modificação genética de humanos, controle populacional, eliminação de doenças etc., e, no meio desse debate, surgiram ideias sobre a necessidade de nova ética fundada sobre a ciência evolucionista. Um exemplo disso é o livro de resumos do evento intitulado "Man and his future", no qual Francis Crick (codescobridor da estrutura do DNA) escreveu "I think that in time the facts of science are going to make us become less Christian. There is eventually bound to be a conflict of values" (apud Evans 2010, p.210).

Esse debate de cientistas sobre a bioética não passou despercebido aos líderes religiosos, principalmente porque os cientistas estavam tocando em questões que, para eles, tinham relação como os significados da vida e da morte, uma área que os teólogos sempre haviam considerado como sua própria área de especialidade. A partir daí, dessa aparente intromissão no campo da teologia, os teólogos passaram, cada vez mais, a se envolver com o tema e a promover debates, os quais foram seguidos por advogados, filósofos, cientistas sociais e outros, tornando-o interdisciplinar.

Para Evans (2010, p.219), a discussão sobre as relações entre ciência e religião podem gerar algumas lições para as questões da bioética. Inicialmente, ele aponta que tem sido um consenso, na bioética, que bioeticistas e filósofos deslocaram os teólogos desse debate pelo fato de seus argumentos serem melhores. Evans convoca a sociologia do conhecimento para rejeitar essa narrativa-padrão, ou seja, o grupo vencedor não é o que tem os melhores argumentos, mas o que tem mais recursos para angariar adeptos. Assim, os argumentos de uma bioética secularista obtiveram predominância, não porque são melhores, mas porque eles se adequavam às necessidades do principal provedor de recursos, ou seja, o Estado burocrático. Portanto, para Evans (2010, p.221), "If we are to focus on ideas in future analyses of ethical conflict between religion and science, we should not presume that one set of ideas will make more sense to people than another."

Para ele, essa ênfase na qualidade das ideias pode levar à construção de uma história whig (presentista), em que a ciência triunfa sobre a religião por conta de suas melhores explicações, e declara que os mais recentes estudos sociológicos têm evitado essa pressuposição, dando mais peso às estratégias por meio das quais determinados grupos, em determinadas épocas, têm manejado os recursos para garantir que sua perspectiva seja verdadeira, seja como ciência, seja como religião.

Outra lição tem a ver com outra narrativapadrão em bioética, a qual argumenta que as descobertas científicas levantam questões morais para as quais a sociedade deve desenvolver sistemas éticos. Como, por exemplo, a psicologia evolucionária tenta mostrar que o comportamento humano não é guiado por uma moral, mas pelos genes gerados há milhões de anos atrás, através de mudanças no processo de evolução. No entanto, para Evans (2010), o que abala a moral da sociedade não são as descobertas da ciência, mas seus interesses institucionais de não deixar que o público seja capaz de debater seus propósitos. 
Amilcar Baiardi, Fabihana Souza Mendes, Wellington Gil Rodrigues

A última lição apontada por Evans é a de que o conflito entre ciência e religião, no campo da bioética, não é tanto sobre epistemologia, mas sim sobre valores. Para Evans (2010, p. 222) "At least in the contemporary world, science should be viewed not only as a knowledge producer, but as an institution with values, interests and resources that competes with many others, including religion."

\section{OBJETO E METODOLOGIA}

O objeto da investigação é avaliar as diferentes reações a símbolos e ícones que representem avanços da ciência. Esta pesquisa se propõe a fazer uma sistematização de como os elementos simbólicos e os cânones da ciência moderna (terapias ou procedimentos de modificação genética, uso de células-tronco, clonagem, etc.) são percebidos com uma maior tolerância ou resistência por diferentes sistemas de crença.

A pesquisa consistiu de uma abordagem empírica, com uso de questionário que compreen- dia questões sobre ciência, religião e bioética. O questionário foi estruturado em torno de três temas principais: 1) métodos contraceptivos;2) pesquisa genética; e 3) intervenções quanto ao fim da vida. As religiões representadas na pesquisa foram Catolicismo, Afro-brasileira, Espiritismo, Protestantismo tradicional (Assembleia de Deus, Batista), Protestantismo neopentecostal (Universal do Reino de Deus, Mundial do Poder de Deus), Adventista e Testemunhas de Jeová. Ao todo, foram entrevistados 12 líderes dessas religióes, cujas respostas foram tabuladas e representadas em tabelas e gráficos expressando a distribuição das variáveis e a frequência.

Cada pergunta teve três possíveis respostas: a) totalmente a favor, $\mathbf{F}$, (quando a crença religiosa concorda completamente com essa prática, ou não vê nenhum problema com ela); b) totalmente contra, C, (quando a crença religiosa discorda completamente dessa prática); c) A favor só em certos casos, FS, (quando aprova somente uma intervenção específica e não o procedimento de um modo geral). O perfil dos líderes entrevistados é apresentado no Quadro1.

Quadro 1 - Perfil dos líderes religiosos entrevistados

\begin{tabular}{|c|c|c|c|c|}
\hline Líder religioso & Idade & Gênero & $\begin{array}{c}\text { Tempo de atuação } \\
\text { na liderança }\end{array}$ & Formação escolar \\
\hline Religião afro-brasileira 1 & 74 & Masculino & 25 anos & $3^{\mathrm{a}}$ série \\
\hline Religião afro-brasileira 2 & 33 & Masculino & 15 anos & $8^{\mathrm{a}}$ série \\
\hline Adventista 1 & 38 & Masculino & 14 anos & Graduação em Teologia \\
\hline Adventista 2 & 53 & Masculino & 22 anos & Doutorado em Teologia \\
\hline Católico 1 & 40 & Masculino & 7 anos & $\begin{array}{c}\text { Graduação em Filosofia, } \\
\text { Teologia e Museologia }\end{array}$ \\
\hline Católico 2 & 41 & Masculino & 20 anos & Doutor em Teologia \\
\hline Espírita & - & Feminino & 1 ano e 2 meses & Graduação em Pedagogia \\
\hline $\begin{array}{l}\text { Neopentecostal 1, } \\
\text { Igreja Mundial }\end{array}$ & 45 & Masculino & 20 anos & $\begin{array}{l}\text { Graduação em Educação } \\
\text { Física e Teologia }\end{array}$ \\
\hline $\begin{array}{l}\text { Neopentecostal 2, } \\
\text { Igreja Universal } \\
\end{array}$ & 52 & Masculino & 5 anos & Ensino Médio \\
\hline $\begin{array}{l}\text { Protestante Tradicional 1, } \\
\text { Assembleia de Deus }\end{array}$ & 61 & Masculino & - & Graduação em Teologia \\
\hline $\begin{array}{l}\text { Protestante Tradicional 2, } \\
\text { Igreja Batista }\end{array}$ & 38 & Masculino & 7 anos & $\begin{array}{c}\text { Graduação em Teologia } \\
\text { e Filosofia }\end{array}$ \\
\hline Testemunha de Jeová & 43 & Masculino & 17 anos & Ensino Médio \\
\hline
\end{tabular}


ANÁLISE E DISCUSSÃO DOS RESULTADOS

\section{Métodos contraceptivos}

Os métodos contraceptivos podem ser divididos didaticamente em: Gráfico 2 - Métodos comportamentais - abstinência sexual (\%) comportamentais, de barreira, métodos hormonais e cirúrgicos. Em relação ao métodocontraceptivo comportamental, o da "tabelinha”, 100\% dos líderes entrevistados se posicionaram a favor de seu uso, talvez pelo fato de ser considerado o mais natural possível, não exigindo interferências externas ao organismo feminino. Somente um líder católico comentou a possível falibilidade do método.

Quanto ao método comportamental do “coito interrompido”, a Fonte: Pesquisa de campo. maioria foi a favor, 10 em 12 (83\%). No entanto, os dois líderes católicos, 2 em 12 (17\%), se posicionaram contra, e um deles alegou que é um postura com implicações psicológicas negativas para o casal. Enquanto alguns protestantes tradicionais alegaram que isso seria um "procedimento não bíblico", os neopentecostais alegaram que isso depende da decisão do casal, e a igreja não deve interferir (Gráfico 1).

Em se tratando do método comportamental a favor, 3 em 12 a favor só em certos casos (25\%) e contra (8\%). Os únicos líderes unânimes na negativa em relação ao uso desse método foram os neopentecostais e os adventistas (Gráfico 2).

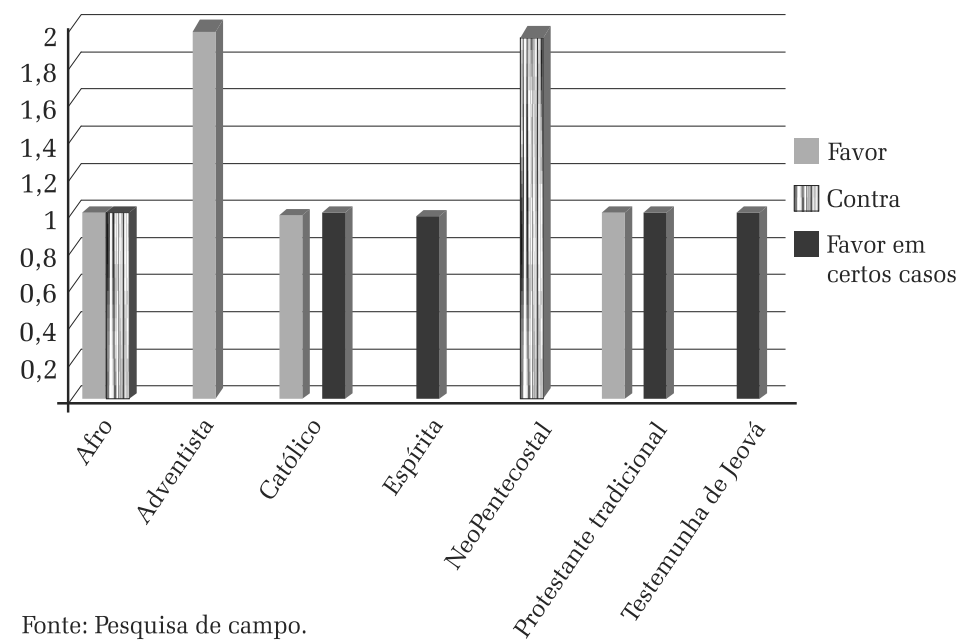

Avalia-se que tanto a aceitação como a negação desse método pelos líderes tem basicamente a mesma razão, ou seja, a preservação de certa pureza ou castidade e obediência a Deus e à Igreja. No caso dos que concordaram com o método, suas respostas revelam que eles estão focados nos jovens solteiros e que apoiam a abstinência como meio de se proteger de doenças e também de obedecer à Igreja e a Deus. No caso dos que foram contra o uso da abstinência, avalia-se que eles estão focados em ca-
Gráfico 1 - Métodos comportamentais - coito interrompido (\%)

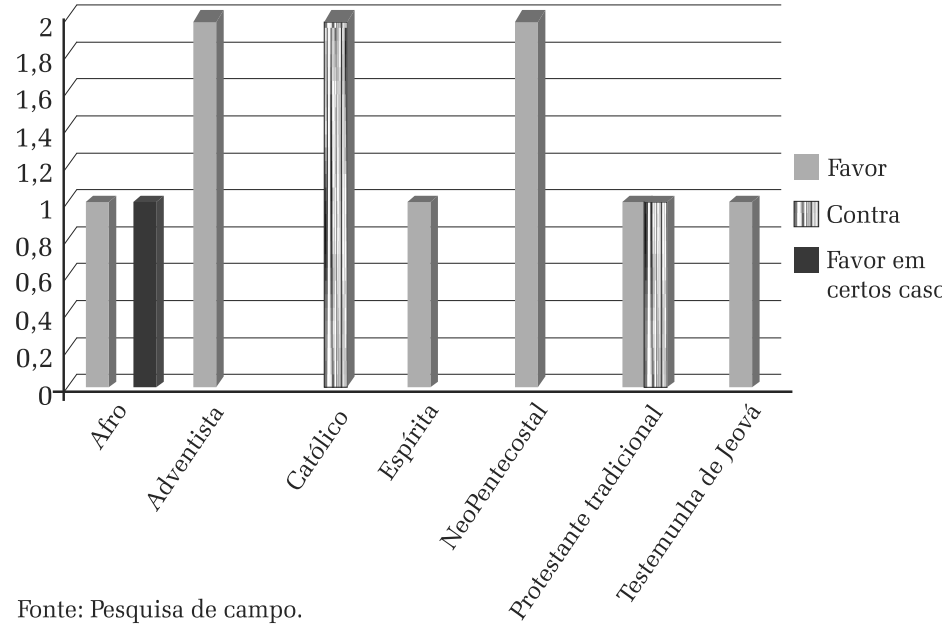
sais casados e entenderam a abstinência sexual do casal como uma forma de desobediência à ordem de Deus de crescer e multiplicar.

Quanto ao preservativo “camisinha” (Gráfico 3), um método contraceptivo de barreira, a grande maioria, 9 em 12 (75\%), se posicionou a favor, um líder católico e um protestante tradicional se posicionaram a favor em certos casos (17\%) e uma liderança católica, $8 \%$, se posicionou contra, mas não deu suas razões. O líder católico que se posicionou a favor só em certos 
Amilcar Baiardi, Fabihana Souza Mendes, Wellington Gil Rodrigues

Gráfico 3 - Métodos de barreira - preservativo “camisinha” (\%)

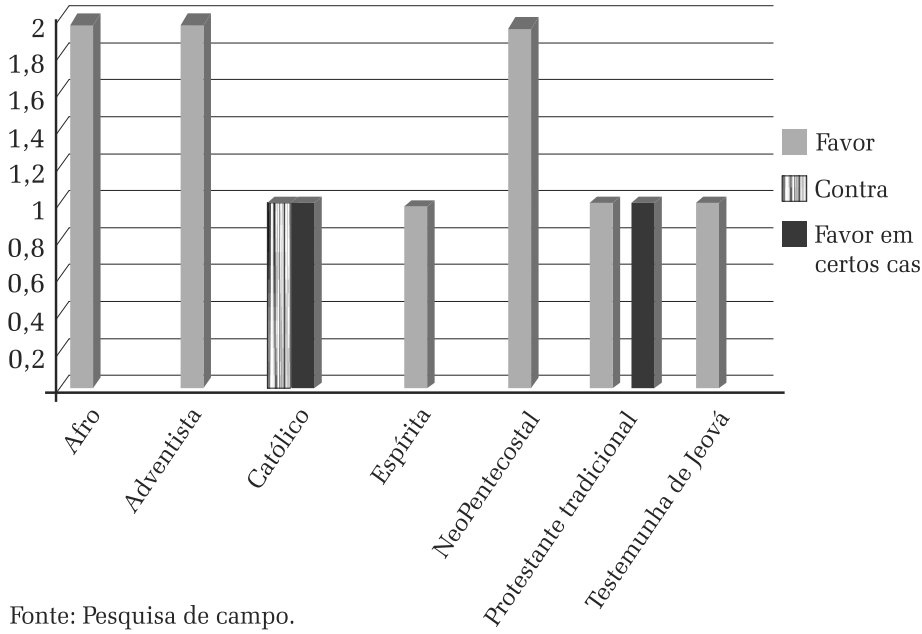

[...] DIU é o método que faz com que o corpo da mulher se torne um lugar inóspito, sem vida. Sabendo que o mecanismo do DIU provoca a impossibilidade da nidação, o DIU tem caráter abortivo porque, na verdade, quando o ovulo sai das trompas e se aloja no útero ele não pode se alojar, pois o DIU gera um processo de inflamação, não permitindo a fecundação (Líder Católico 2).

Interpreta-se que o apoio ou não ao uso do DIU está relacionado à perspectiva do líder religioso sobre o caráter abortivo ou não abortivo desse método, ou seja, se o líder entende que ele éabortivo, há uma tendência a se posicionar contra e, se ele entende casos declarou que: “[...] no caso da camisinha, a visão católica é sempre contrária. Em algumas situações, o homem que contraiu AIDS e que ainda tem relação com a sua esposa deve usar”.

Em relação ao uso do dispositivo intrauterino (DIU), metade dos líderes é favorável a seu uso, e os que são contrários, 4 em 12, somaram $34 \%$. Os $16 \%$ restantes são os que não responderam ou manifestaram ser a favor somente em certos casos. Uma visualização dessa distribuição encontra-se no Gráfico 4. A única filiação reli-

Gráfico 4 - Métodos de barreira - dispositivo intrauterino, DIU (\%)

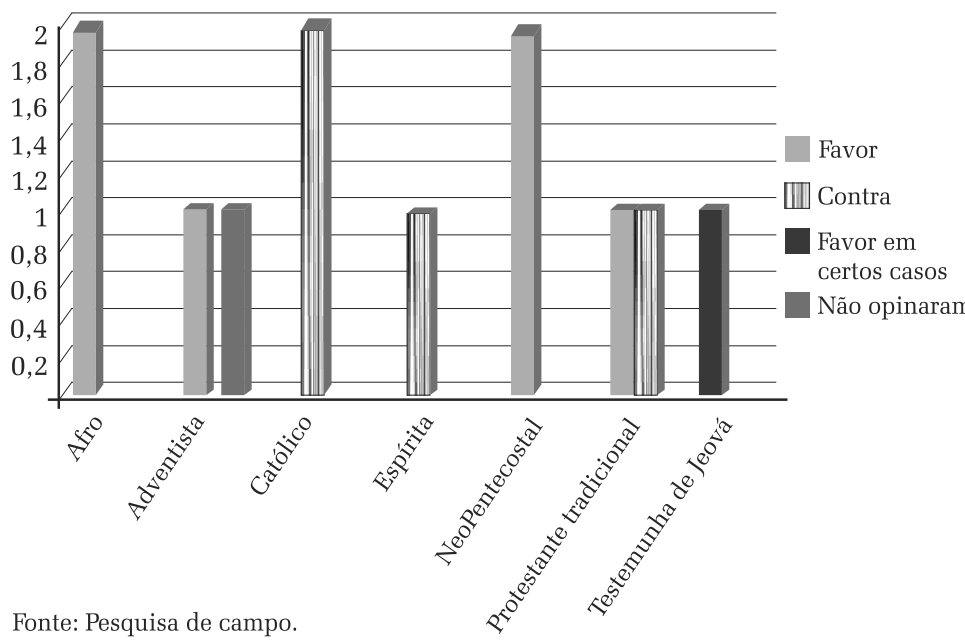

b) evitar problemas de saúde para a mulher (ver a distribuição das respostas no Gráfico 5).

A moral da igreja é naturalista no sentido de que tudo aquilo que impede a execução natural da ação humana não é visto de uma forma positiva [...]não se deve interferir no mecanismo natural. [...] há estudos que falam que alguns distúrbios da saúde são provocados pelos anticoncepcionais que interferem no mecanismo natural do corpo, do mesmo jeito que a pílula do dia seguinte, que tem caráter abortivo (Líder Católico 2).

Quanto ao método hormonal chamado "pílula do dia giosa unânime contra ao uso do DIU foi a católica, e um de seus representantes destacou o aspecto abortivo desse dispositivo: seguinte”, metade dos líderes optou por ser contrário a seu uso. Os que se colocaram a favor foram 5 em 12 (42\%,), e 8\% optaram por “a favor só em 
Gráfico 5 - Métodos hormonais - Pílulas Anticoncepcionais (\%)

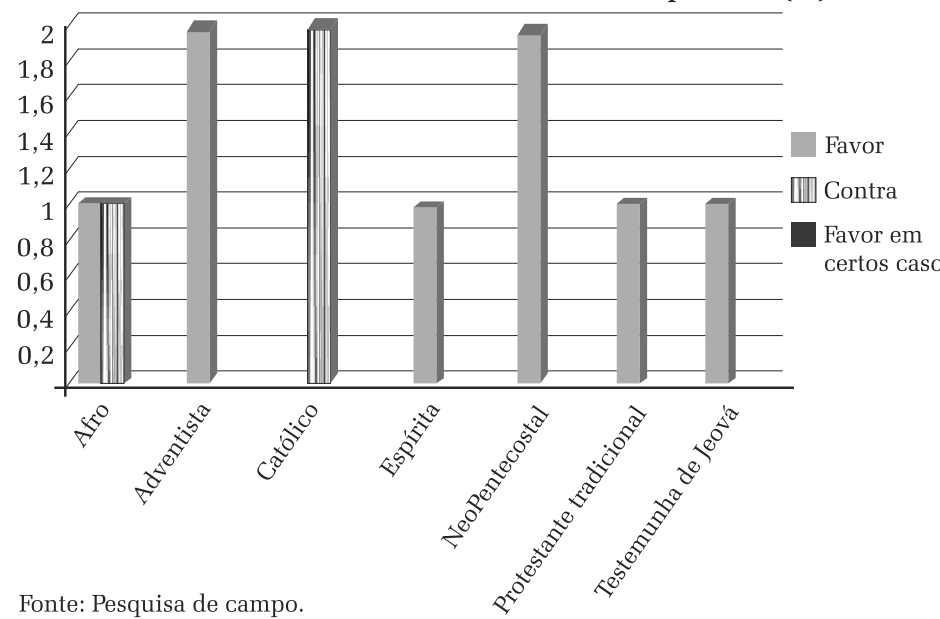

ões afro-brasileiras e os adventistas. Os percentuais dos que foram contrários e a favor, em certos casos, foram equivalentes, $25 \%$ cada, como informa o Gráfico 7. Os líderes de religiões afro-brasileiras apresentaram como justificativa os argumentos, 'É bom para não ter muitos filhos e depois não ter condição de criar" (Líder de religião afro-brasileira 1). Para controlar a natalidade (Líder de religião afro-brasileira 2).

Houve também unanimidade dos líderes católicos, que foram concertos casos". No entanto, foi um dos métodos que trários a esses métodos. Um deles justificou esse mais provocou divergência de opiniões entre os posicionamento invocando um conflito pratica-

Gráfico 6 - Métodos Hormonais - Pílula do dia seguinte (\%)

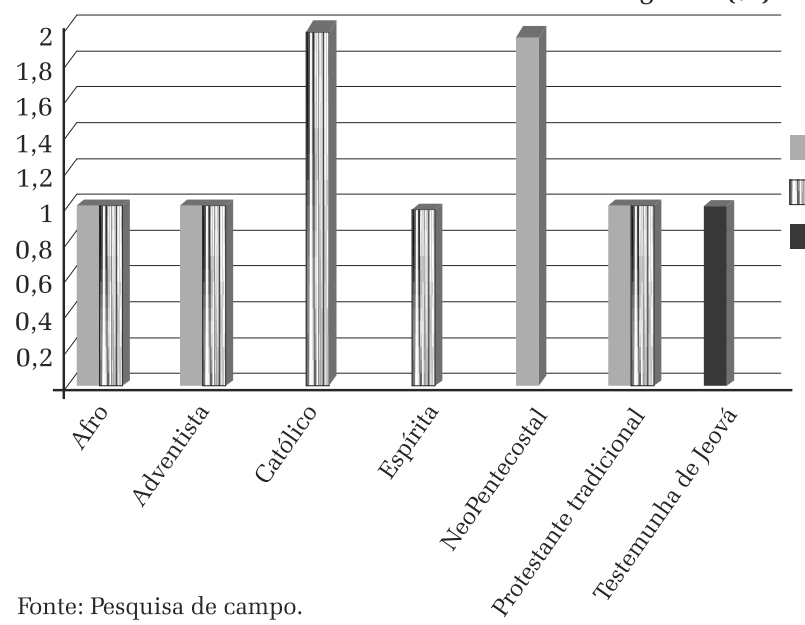

mente inevitável entre a vontade do sujeito e a moral da igreja:

Somos contra a laqueadura e vasectomia, pois interferem na anatomia, sobretudo quando não há retorno. Em alguns casos pode ser que seja a última expressão. A moral católica é muito restritiva, nem sempre a gente faz na vida o que é ideal. A nossa vida é um conflito entre ideal e real.

Quanto ao método cirúrgico do aborto, $58 \%$ dos entrevistados foram totalmente contra e $33 \%$ foram a favor só em certos casos muito especiais, havendo somente um

líderes da mesma religião, pois só houve unanimidade entre os católicos, que foram contrários, e entre os neopentecostais, a favor (ver Gráfico 6). Os neopentecostais apresentaram como razão o fato de considerarem a pílula do dia seguinte um método não abortivo.

Em se tratando dos métodos cirúrgicos e considerando-se, mais especificamente, a laqueadura e a vasectomia, $50 \%$ se posicionaram a favor e, entre esses, houve unanimidade por parte dos líderes de religi- Fonte: Pesquisa de campo.

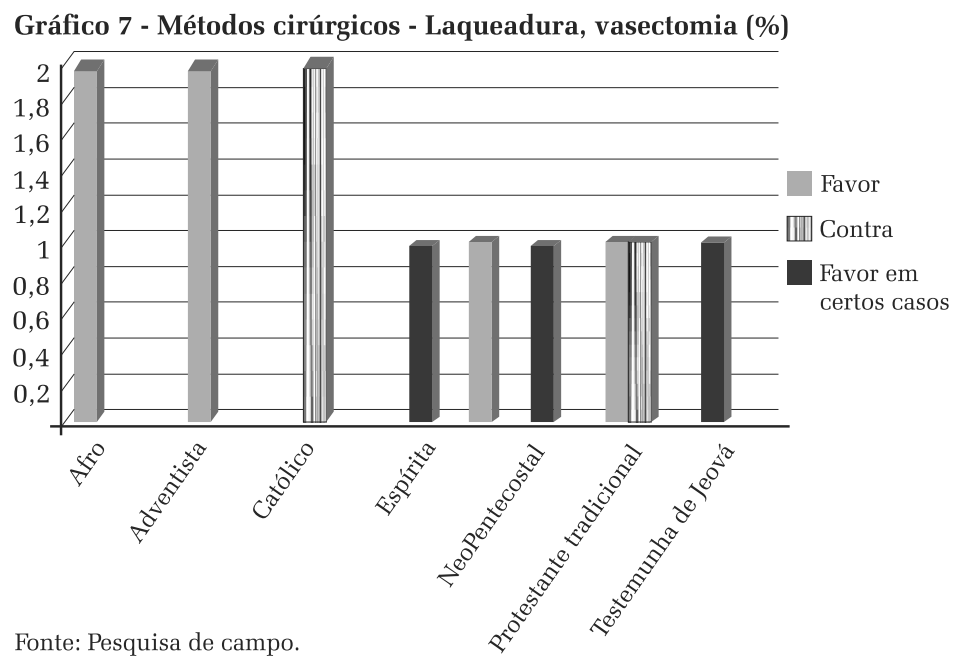


Amilcar Baiardi, Fabihana Souza Mendes, Wellington Gil Rodrigues

posicionamento plenamente a favor. A grande maioria dos líderes religiosos se colocou contra esse método, como deixa claro o Gráfico 8.

Gráfico 8 - Métodos Cirúrgicos - Aborto (\%)

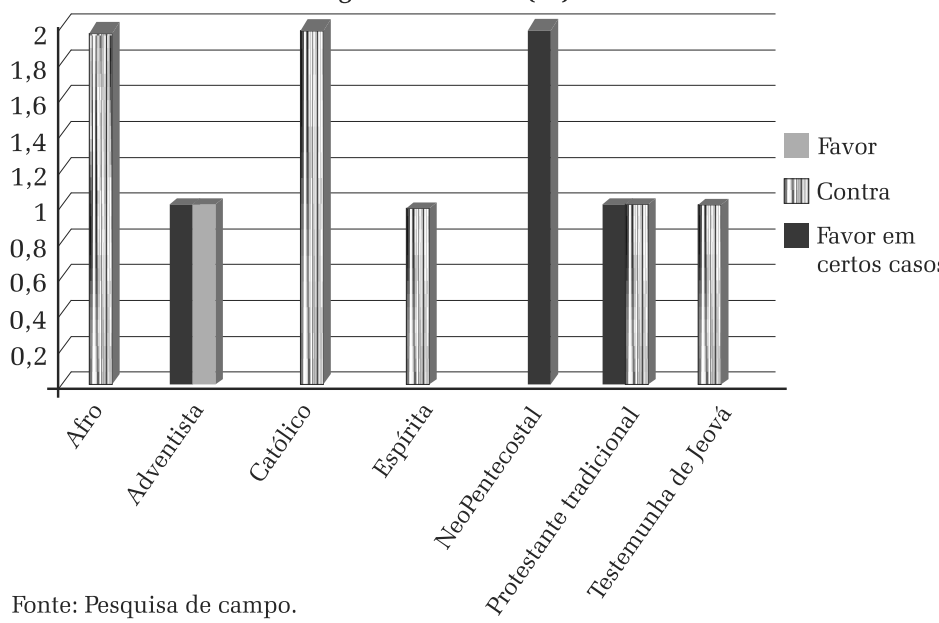

estão: clonagem animal, clonagem humana, utilização de células-tronco embrionárias em pesquisas, produção de órgãos humanos em laboratório e cruzamento de genes entre espécies.

Em relação à clonagem animal, metade dos líderes se posicionou contra, $33 \%$ a favor e 17\% a favor só em certos casos (Gráfico 9). A única unanimidade entre os líderes de uma mesma religião se deu entre os neopentecostais, um dos quais declarou: “[...] só Deus dá a vida e é o único que pode criar alguma coisa, e não um pecador" (Líder Neopentecostal 2, Igreja Universal). Os católicos se dividiram entre contra e a favor. O líder que se posicionou a favor argumentou que:

Osprotestantesneopentecostais Gráfico 9 - Clonagem animal (\%)

e tradicionais se preocuparam em justificar seus posicionamentos "a favor só em certos casos”, declarando: "Contra o aborto, mas se existir deformidade genética, a Igreja é a favor" (Líder Neopentecostal 1, Igreja Mundial). Só em caso de estupro (Líder Neopentecostal 2, Igreja Universal).

Só sou a favor ao aborto, em certo casos. Quando oferece risco de vida da mãe, acho que o aborto é razoável; em outros casos não, porque vai de encontro com a pa- Fonte: Pesquisa de campo. lavra de Deus. Quando alguém aborta uma vida, se torna um assassino, e os assassinos não têm parte com Deus, a não ser que se arrependam e não voltem a praticar mais estes erros sórdidos e pérfidos. (Ap.21:8), (I Coríntios 7). (Líder Protestante Tradicional 2, Igreja Batista).

\section{Pesquisa genética}

A área da pesquisa genética é uma das que mais têm trazido desafios para as relações entre conhecimento e prática científica e as crenças e práticas religiosas. Entre as principais questões, medicamentos”(Líder Adventista 1).

"[...] é a favor da Clonagem animal desde que a ciência tenha a possibilidade de, no futuro, resolver alguns problemas, como espécies em extinção" (Líder Católico 2). Outro líder que se declarou a favor afirmou: "[...] sou a favor quando se tem um parâmetro cientifico em causa de boa ação e progresso para a humanidade" (Líder Protestante Tradicional 2, Igreja Batista). Entre os que se declararam a favor só em certos casos, destaca-se a seguinte declaração: “[...] a favor quando tem como objetivo atender a preservações de espécies e fazer 
A metade que se posicionou contra não elaborou as justificativas para esse posicionamento. Os outros que posicionaram a favor e a favor só em certos casos invocaram argumentos baseados nos benefícios que podem ser obtidos da ciência, tanto para a vida humana (produção de remédios) como para a vida animal (preservação de espécies).

Em se tratando da clonagem humana, tema bem mais complexo, a grande maioria dos líderes, 10 em 12, (83\%), se posicionou contra, como permite visualizar o Gráfico 10. Somente um dos líderes se posicionou a favor (Líder de Religião afro-

Gráfico 10 - Clonagem humana (\%)

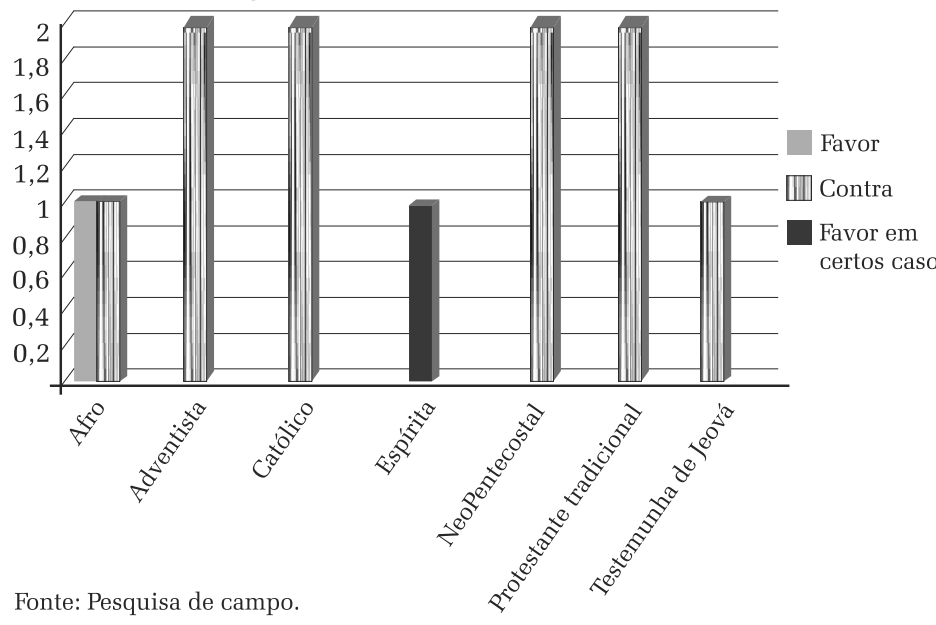

ser percebido no Gráfico 11. A única unanimidade de líderes ocorreu entre os católicos, que se posicionaram contra esse tipo de pesquisa. Contudo, a justificativa do líder católico 2 demonstra que seu posicionamento pode ser flexibilizado em certos casos: “[...] sou contra; mas nos casos em que são utilizadas células do nosso próprio organismo, então sou a favor "(Líder Católico 2). Outro líder que se posicionou contra justificou apelando para a questão do caráter sagrado da vida, mesmo em se tratando de vida embrionária.

Um líder que se posicionou totalmente a favor desse tipo de pesquisa argumentou com os benefícios prometidos pelo avanço desse tipo de pesquisa: “[...] sou a favor da pesquisa e da célula-tronco com o objetivo de combater e ajudar nas mais variadas enfermidades, pois se estabelece um progresso pela vida” (Filipenses 4:8). (Líder Protestante Tradicional 2, Igreja Batista).

No que diz respeito à produção de órgãos humanos em laboratórios, $42 \%$ dos líderes se posicionaram contra, $33 \%$ a favor e $25 \%$ a favor só em certos casos, com a distribuição brasileira 1) e somente um outro escolheu a favor só em certos casos (Líder Espírita). No entanto, eles não justificaram essa escolha. Entre os que se posicionaram contra, podem-se perceber diversas justificativas, as quais apelam tanto para uma "moral naturalista", no caso dos católicos, como para uma 1 incapacidade de a ciência criar um ser humano dotado de personalidade (Líder Neopentecostal 2, Igreja Universal).

Quanto à utilização de células-tronco embrionárias em pesquisas genéticas, houve uma grande diversidade de posicionamentos, $42 \%$ contra, $33 \%$ a favor e $25 \%$ distribuídos em não se manifestando e a favor só em certos casos, o que pode Fonte: Pesquisa de campo.

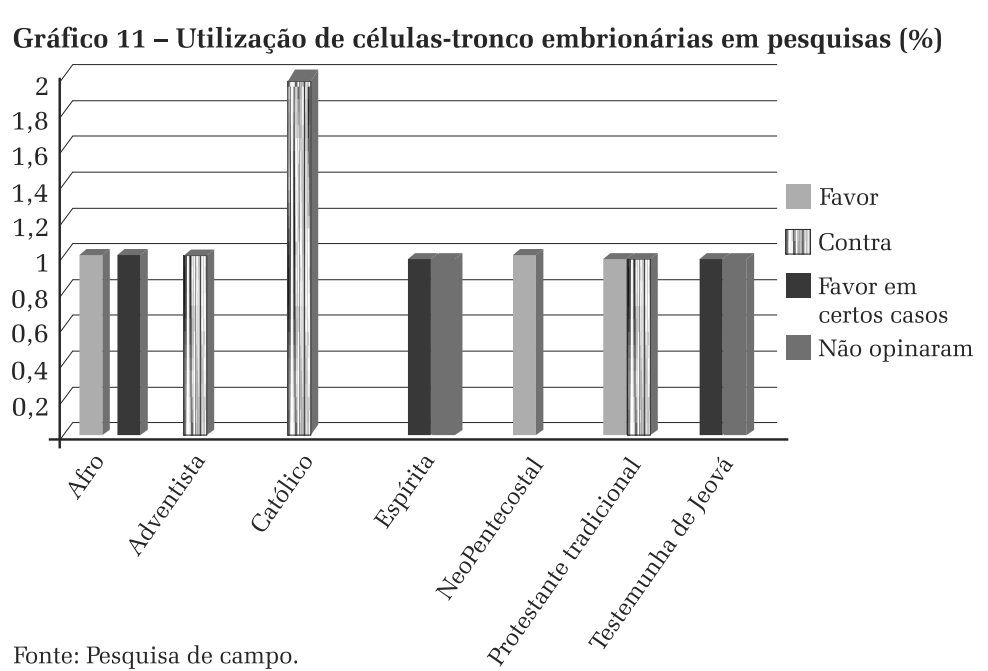


Amilcar Baiardi, Fabihana Souza Mendes, Wellington Gil Rodrigues

Gráfico 12 - Produção de órgãos humanos em laboratório (\%)

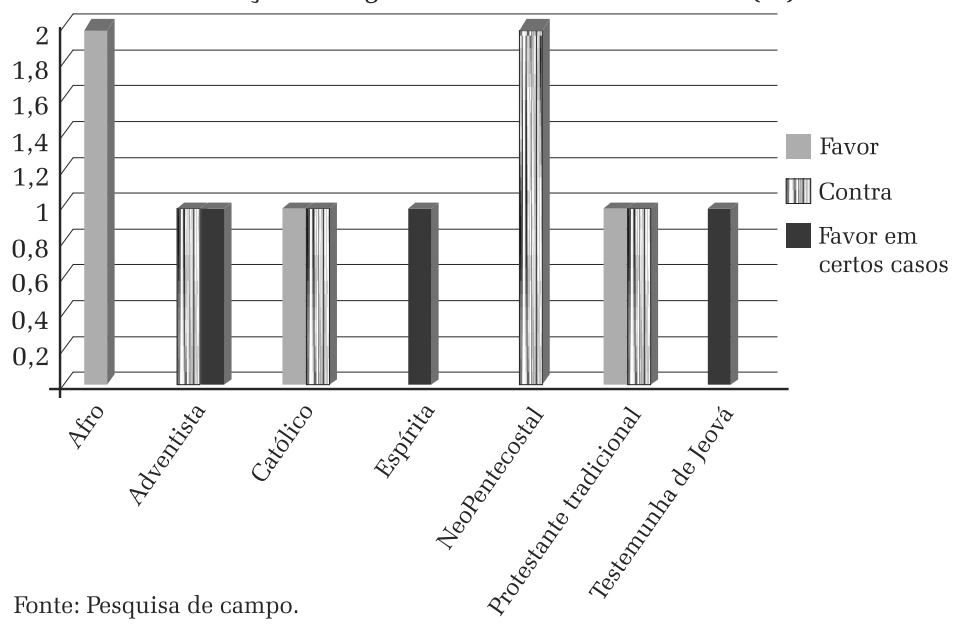

ferentes espécies fazem referência a um perigo de interferir em uma ordem natural estabelecida por Deus, o que, de certa forma, contraria as argumentações sobre o papel da ciência de melhorar a natureza: “[...] é perigoso mudar o padrão genético (Líder Adventista 1). A igreja é contra tudo que interfira na vida”(Líder Católico 1).

O único líder que se posicionou francamente a favor (Líder Protestante Tradicional 2, Igreja Batista) argumentou com os neopentecostais apresentaram unanimidade contra e justificaram assim: "É uma forma que mata os seres humanos”. (Líder Neopentecostal 1, Igreja Mundial). "Sou a favor do transplante e não da produção em laboratório”. (Líder Neopentecostal 2, Igreja Universal).

Os líderes católicos se dividiram entre contra e a favor, e a argumentação a favor invoca uma função corretiva da ciência diante de uma natureza que é falha: "[...] sobre a produção de órgão em laboratório sou a favor, pois a tarefa da ciência é corretiva se, por alguns instantes, a natureza falha” (Líder Católico 2).

Os líderes protestantes tradicionais também se dividiram na resposta entre a favor e contra, e a argumentação a favor foi muito semelhante à do líder católico, ou seja, de que a ciência pode ser utilizada para corrigir ou melhorar a natureza.

Outro tema bastante polêmico e que tem estado muito presente na opinião pública atual, nos filmes e nos jornais (mutação, geração de novas espécies etc.) trata da hibridação induzida entre espécies. A forma como se distribuíram as respostas é apresentada no Gráfico 13, o qual mostra que 75\% dos entrevistados se posicionaram contra. Algumas argumentações contrárias ao cruzamento entre di-

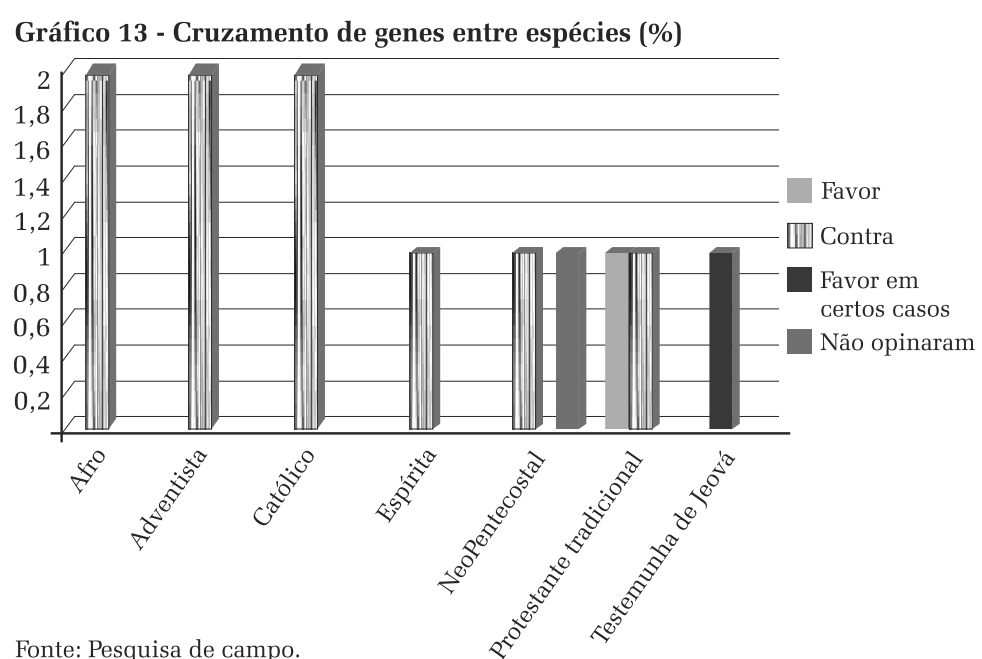

benefícios trazidos pelo cruzamento entre espécies, apresentando, como exemplo, o resultado do cruzamento do cavalo com o jumento, a mula ou burro. No entanto, esse tipo de cruzamento ocorre espontaneamente na natureza e talvez não possa ser considerado entre espécies diferentes, já que eles geram cria.

\section{Intervenções quanto ao fim da vida}

O tema dos limites da vida e das intervenções médicas em relação a esse limite tem gerado vários questionamentos na interação entre ciência e religião. Esse tema se torna mais delicado ainda ao se entender que cada pessoa tem o direito de dispor de sua vida como queira, mas a indução da 
morte, que é um fator natural biológico, requereria uma reflexão mais aprofundada, por envolver os mais variados sentimentos dos parentes e dos que estão ligados ao enfermo. O sentimento de piedade tem explicado medidas radicais, a fim de aliviar por completo o sofrimento daquele que está no leito, mas em vida vegetativa. Não obstante poder parecer racional a interrupção da vida, de acordo com as manifestações de parte do público pesquisado, não se autoriza a pensar dessa forma. Das várias categorias de intervenção médica sobre o paciente terminal, a seguir são apresentados os quatro tipos principais utilizados na pesquisa.

A eutanásia dispõe, para os pacientes, a oportunidade de decidirem se querem continuar vivos ou não, interrompendo os fenômenos biológicos, ainda que deficientes, porém ainda existentes, mas com rara chance de reversibilidade, por meio da retirada dos aparelhos ou supressão de medicamentos.

A ortotanásia representa a suspensão de procedimentos ou tratamentos que têm como objetivo a manutenção artificial da vida de um paciente terminal, com enfermidade grave e (ou) incurável, deixando-o morrer naturalmente e de uma forma mais confortável e rápida. Os médicos consideram esse procedimento uma "forma higiênica” de se morrer, ou "morrer bem"; mas ele pode ser considerado um sinônimo da eutanásia.

A distanásia é o prolongamento artificial da vida de um paciente terminal sem perspectiva de cura ou melhora, através de sedação e da administração de medicamentos que promovem a continuidade do trabalho de algumas células.

O suicídio assistido ocorre quando uma pessoa ajuda outra a se matar. Por exemplo, quando um médico prescreve um veneno, ou quando uma pessoa põe, no paciente, uma máscara ligada a uma botija de monóxido de carbono e lhe dá instruções sobre como ligar o gás, de forma a morrer.
Em relação ao tema da eutanásia, a grande maioria, 75\%, se posicionou contra, conforme pode ser observado no Gráfico 14.

ásia (\%)

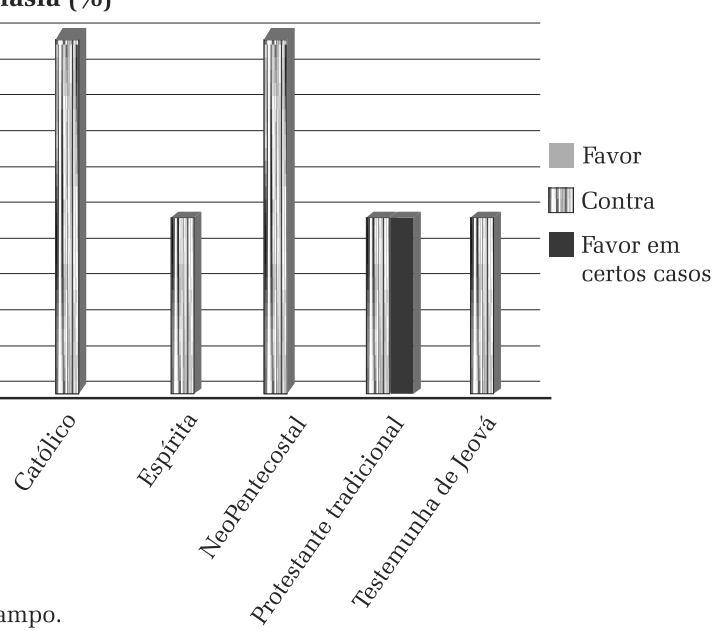

Somente os líderes de religião afro-brasileira foram unanimemente favoráveis ao uso da eutanásia, mas não apresentaram justificativas. Entre os líderes que se posicionaram contra, destacamse as seguintes declarações:

Partimos do princípio de que Deus é o autor da vida e deve ser respeitado do início ao termino (Líder Católico 1).

Somos contrários a qualquer método de eutanásia que objetive abreviar a vida, antecipando a desencarnação. (Líder Espírita 1)

Somente Deus pode dar ou tirar a vida de qualquer ser humano (Líder Neopentecostal 1, Igreja Mundial).

Mesmo ele pedindo isso, mostra que ainda existe vida e, enquanto há vida, há esperança; só Deus pode tirar a vida. Não importa o sofrimento, Deus sabe o momento certo (Líder Neopentecostal 2, Igreja Universal).

Enquanto a soberana vontade de Deus sobre a vida do paciente é invocada entre os que foram a favor, um dos líderes que optou pela posição "só em certos casos" argumenta levar em consideração a vontade da família ou do paciente:

Porque devemos proporcionar respeito à vontade da família ou do ente debilitado (Líder Protestante Tradicional 2, Igreja Batista).

No que se refere ao procedimento da 
Amilcar Baiardi, Fabihana Souza Mendes, Wellington Gil Rodrigues

ortotanásia, 42\% dos líderes se posicionaram contra, $42 \%$ se posicionaram a favor, 5 em 12, em ambos os casos, e 16\% escolheram "a favor só em certas condições”, como se representa no Gráfico 15.

Gráfico 15 - Ortotanásia (\%)

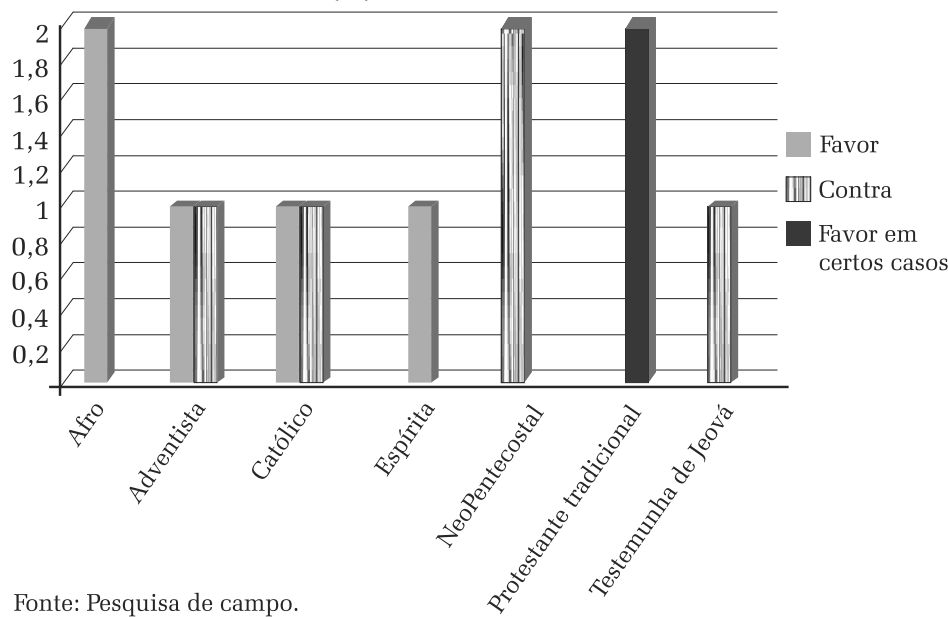

Somente os líderes de religião afro-brasileira foram unânimes no posicionamento a favor, embora não justificassem. O líder espírita se posicionou a favor e justificou com a seguinte declaração:

Somos favoráveis à ortotanásia, compreendendose como sendo um método de permitir a desencarnação no tempo certo, com alívio das dores e não incorrendo em prolongamento abusivo com aplicação de meios inapropriados, que imporiam sofrimentos adicionais (Líder Espírita).

Os líderes neopentecostais foram unânimes no posicionamento contra e justificaram: "Somente Deus pode dar ou tirar a vida de qualquer ser humano" (Líder Neopentecostal 1, Igreja Mundial). "Não se deve parar de oferecer o medicamento e de maneira nenhuma fazer suspensão de medicamento; deve tratar o paciente como um todo" (Líder Neopentecostal 2, Igreja Universal).

Os líderes católicos e adventistas estavam divididos entre as posições a favor e contra, e um dos líderes adventistas assim justificou sua posição contrária, Fonte: Pesquisa de campo. interpretando a ortotanásia como um sinônimo de eutanásia: "Contra porque é uma forma de eutanásia, porque a pessoa podia fazer alguma coisa mais não fez”(Líder Adventista 1).

Os protestantes tradicionais foram unânimes no posicionamento "a favor só em certos casos", e seus posicionamentos basearam-se no conhecimento técnico do médico e na confusão de conceitos entre eutanásia e ortotanásia: Com prescrição medica. (Líder Protestante Tradicional 1, Assembleia de Deus).

Isso é muito relativo, podemos ver o exemplo do filme "Menina de ouro", onde o autor conceitua ortotanásia, tentada no caso como algo pessoal e familiar para atenuar um imenso sofrimento de todos (Líder Protestante Tradicional 2, Igreja Batista).

No que tange à distanásia, metade dos líderes se posicionou contra, $25 \%$ a favor, $17 \%$ só em certos casos e 8\% não se manifestou (ver Gráfico 16). Os líderes de religião afro-brasileira foram unânimes na sua posição contra, mas não justificaram. Os líderes católicos e adventistas ficaram divididos entre os posicionamentos contra e a favor, mas o único argumento apresentado a favor foi de um líder adventista:

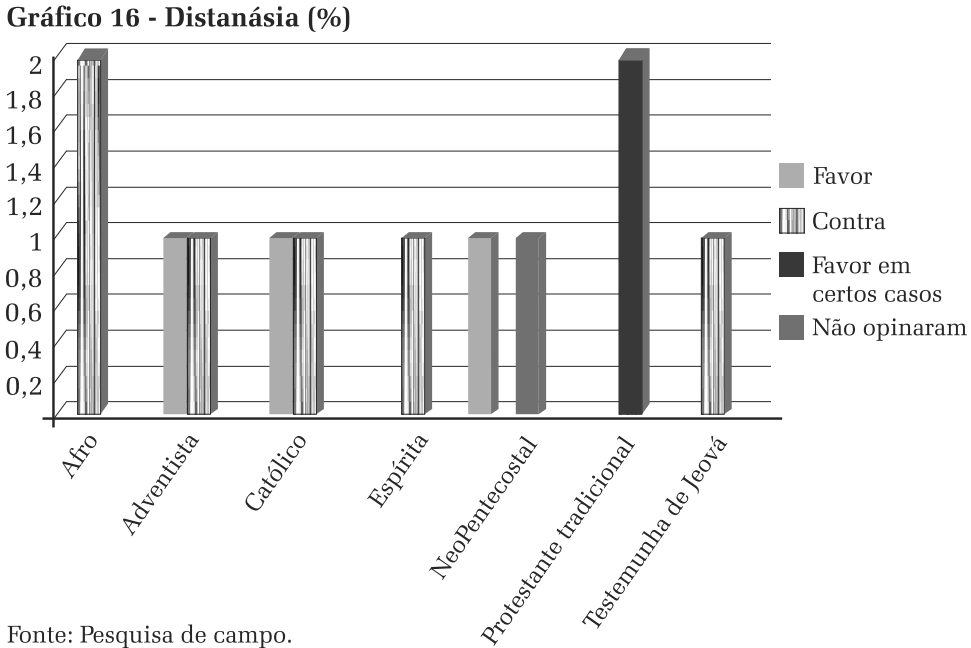


A igreja adventista apoia o uso da medicina moderna para prolongar a vida humana. Todavia, deve ser utilizada de maneira compassiva, que revele a graça divina, minimizando o sofrimento (Líder Adventista 1).

O líder espírita apresentou um argumento bem preciso e lógico sobre quando não utilizar esse método, através da avaliação dos custos e dos benefícios dos tratamentos paliativos:

Somos contrários à distanásia como meio de prolongar a vida do paciente, utilizando-se de processos terapêuticos cujos efeitos são mais nocivos do que os efeitos do mal a curar, ou inúteis, porque a cura é impossível e o benefício esperado é menor que os inconvenientes previsíveis.

Os protestantes tradicionais concordaram no posicionamento "a favor só em certos casos" ao uso da distanásia, quando baseado em prescrição médica ou no desejo do próprio paciente.

Em relação ao suicídio assistido, essa foi a única resposta unânime, contra o seu uso, por parte dos líderes, provavelmente embasados em uma ética que propõe Deus como único doador da vida e, portanto, da negação peremptória do próprio indivíduo (com a ajuda de terceiros ou não) vir a tomar a decisão de pôr um termo a um dom considerado divino, ou seja, a vida. Alguns dos argumentos utilizados pelos líderes são:

Somos contrários a qualquer método de suicídio assistido, que se compreende como um ato voluntário do médico, abreviando a vida do paciente, a pedido deste. (Líder Espírita).

Porque o suicídio, segundo a Bíblia, não é permitido, pois vem de encontro à lei de vida pela vida. A Bíblia é referencial, destacando esse livro como um guia de conduta humana. Baseado em Genesis 2 , onde Deus criou o ser humano e estabeleceu a vida é que responde essas questões sobre as intervenções quanto ao fim da vida. (Líder Protestante Tradicional 2, Igreja Batista).

\section{CONSIDERAÇÕES FINAIS}

Há uma tendência a se concluir que existe uma estreita relação entre o nível de formação educacional do líder e o nível de abertura e liberalismo em relação às práticas da ciência, no confronto com as crenças religiosas. No entanto, o que a pesquisa revelou foi que o maior nível de educação formal dos líderes, encontrado nas fileiras da igreja católica, estava associado com posições mais conservadoras, principalmente nos temas relacionados à sexualidade e à reprodução. Por outro lado, percebe-se claramente que, nessa filiação religiosa, existe um alto grau de afinidade doutrinária entre seus líderes. Foram os que mais convergiram nas respostas, as quais, geralmente, demonstraram posicionamentos contrários a certas práticas recomendadas pela ciência, quando elas contrariavam dogmas. Isso talvez se deva ao fato de o processo de formação exigido para se tornar um líder católico ser longo e rígido, e uma grande ênfase ser dada à hierarquia, a qual, de certa forma, concorre para harmonizar as opiniões de seus líderes.

Na outra ponta do nível de formação encontram-se os líderes de religião afro-brasileira, com o menor nível de educação formal no grupo entrevistado, o que talvez reflita o quadro mais geral da situação desprivilegiada da população negra no Brasil, em comparação com outras etnias, no que se refere ao nível econômico e ao acesso à educação. A falta de unanimidade dos líderes de religião afro-brasileira talvez reflita diferentes visões de mundo decorrentes do fato de serem de gerações separadas por vários anos, de terem tido experiências diversas e nível educacional diferente. Contudo, inequivocamente, foram os líderes religiosos afro-brasileiros, os que demonstraram maior abertura em relação aos avanços/práticas científicas.

A religião denominada Testemunhas de Jeová não exige uma formação escolar específica para constituir uma pessoa como líder de suas congregações. Basta que ela se destaque como líder e demonstre espiritualidade. O mesmo parece ocorrer nas igrejas neopentecostais e nas lideranças espíritas. Já os protestantes tradicionais e os adventistas parecem ter um grau maior de exigência em relação à formação de seus líderes, pois geralmente há a exigência de conclusão de um curso superior de Teologia.

Em relação à fundamentação utilizada para justificar seus posicionamentos, o que se observa 
Amilcar Baiardi, Fabihana Souza Mendes, Wellington Gil Rodrigues

é que os protestantes tendem a utilizar bastante a Bíblia como guia de referência para o comportamento de seus fiéis, enquanto os católicos apelam para a tradição moral da igreja e também para argumentos técnicos.

Apesar de os líderes divergirem bastante ao considerar os diferentes temas, pode-se perceber que os princípios básicos por trás dos posicionamentos de todos os líderes giram em torno de reconhecer Deus como doador da vida e da ordem natural do corpo humano e dos ciclos da Terra e, portanto, com o poder exclusivo de interferir nesses processos. Dessa forma, além da intervenção humana ser muito perigosa, ela deve ser feita com muita cautela, ou seja, a ciência só deve alterar essa ordem quando ela se desvia de um suposto plano original perfeito.

Recebido para publicação em 28 de julho de 2013 Aceito em 12 de setembro de 2013

\section{REFERÊNCIAS}

BAIARDI, A. O Imperial Instituto Bahiano de Agricultura e as mudanças na agricultura e na agroindústria da Bahia na segunda metade, do séc. XIX. In: CONGRESSO BRASILEIRO DE HISTÓRIA ECONÔMICA,3., 1999, Curitiba. Anais... Curitiba, 1999. et al. Gênese e transformação das empresas regionais: o recôncavo baiano. Revista do Centro de Artes, $\mathrm{Hu}$ manidades e Letras, Cachoeira,BA, UFRB, v.l., n.1, 2007.

BARBOUR, I. Quando a ciência encontra a religião: inimigas, estranhas ou parceiras. Trad. Paulo Salles. São Paulo: Cultrix, 2004.

BROOKE, J. Science and religion: some historical perspectives. Cambridge: Cambridge University Press, 1999

ENGELHARDT JR., H. T. Fundamentos da Bioética Cristã Ortodoxa. São Paulo: Loyola, 2003.

EVANS, John H. Science, bioethics and religion. In: HARRISON, Peter (Ed.). Companion to science and religion. Cambridge: Cambridge University Press, 2010. p.207-225.

HELLERN, V.; NOTAKER, H. GAARDER, J. O livro das religiões. São Paulo: Companhia das Letras, 2000.

JACOB, C.R.; HEES, D.R.; WANIEZ, P.; BRUSTLEIN, V. Atlas da filiação religiosa e indicadores sociais no Brasil. São Paulo: PUC; Rio de Janeiro: Edições Loyola, 2003.

JANCSÓ, I. Na Bahia contra o império: história do ensaio da sedição de 1798. São Paulo: Hucitec; Salvador: EDUFBA,1996.

MATOSO, K. Bahia século XIX, uma província do Império. Rio de Janeiro: Nova Fronteira, 1992.

NARDI, J. B. Fumo no Brasil colônia. São Paulo: Brasiliense, 1987.

PEACOCKE, A. Theology for a scientific age. Londres: SCM, 1993.

RODRIGUES, W. G.; MOTTA, R. R. S. As relações entre ciência e religião na perspectiva dos professores da FAFIS. Práxis Teológica, Cachoeira,BA, CEPLIB,v.11, n.1, 2011. Disponível em: <http:// www.revistahermeneutica.com.br/index.php/praxis/ article/view/78>.

POLKINGHORNE, J. Belief in god in an age of science. New Haven: Yale University Press, 1998.

TAVARES, L. H. D. Independência do Brasil na Bahia. Salvador: EDUFBA, 2005. 


\section{SCIENTIFIC COSMOPOLITANISM AND LOCAL CULTURES: perception of scientific advances by religious leaders in Recôncavo, Bahia}

\author{
Amilcar Baiardi \\ Fabihana Souza Mendes \\ Wellington Gil Rodrigues
}

Scientific advances in the fields of medicine and biology are perceived in diverse ways, depending on culture, values, and religion, etc. The Recôncavo Bahia, Brazil, a territory that during the colonial period was the province's most important commercial center, and the largest producer of sugar cane and cotton, is emblematic of this condition. In this region demographic groups, made up of descendents of rural producers and their associates, with a Caucasian ethnicity, and by descendents of slaves, with African ethnicity, have, across the centuries, consolidated and transformed their beliefs. A great diversity of beliefs have resulted from these processes; of a Christian origin (Catholicism, Protestantism); of an African origin: (Ilê, Axé, Ogunjá, and Candomblé) with a Nagô and Malé essence including an Islamic influence. These also included beliefs systems a of mixed origin, involving Catholicism and African religious denominations, such as "Boa Morte" and Umbanda. This ample spectrum of religions that coexist without conflict, manifest different reactions to the practices and conduct of contemporary science. Questions such as genetic modification, the use of stem-cells and cloning etc. are viewed differently, with tolerance or resistance, by these belief systems. This work proposes the systematization of the reactions of religious leaders to some of symbols of modern science.

Key-words: Science and religion. Religions of Recôncavo, Bahia, Brazil. Perception of science by religious leaders.
COSMOPOLITISMESCIENTIFIQUEETCULTURES LOCALES: perceptions des progrès de la science par les chefs religieux dans la région du "Recôncavo" de Bahia

\author{
Amilcar Baiardi \\ Fabihana Souza Mendes \\ Wellington Gil Rodrigues
}

Les progrès de la science dans le domaine de la médecine et de la biologie sont perçus différemment en fonction de la culture, des valeurs, de la religiosité, etc. Cela est très emblématique dans la région du "Recôncavo" de Bahia, au Brésil, territoire qui, à l'époque coloniale, fut le plus important centre commercial de la province et son plus grand producteur de canne à sucre et de coton. Dans cette région, des groupes de populations issues de descendants des producteurs ruraux et autres travailleurs y relatif, d'ethnie blanche, ainsi que de descendants d'esclaves, d'ethnie noire, ont métamorphosé et consolidé ces croyances tout au long des siècles. Ces processus ont engendré une grande diversité de croyances, celles d'origine chrétienne, catholicisme et protestantisme, celles d'origine africaine, Ilê Axé Ogunjá et le Candomblé d'essence nagô et Malê, d'influence islamique, mais aussi des croyances aux racines mixtes, mélange de catholicisme et de religions africaines comme le culte de la "Bonne Mort" et l'Umbanda. Toutes ces religions, qui se côtoient sans problèmes, ont cependant des réactions différentes face aux pratiques et aux conduites adoptées par la science contemporaine. Des questions telles que la modification génétique, l'utilisation de cellules souches, le clonage, etc. sont perçues de façon différente par ces systèmes de croyances, soit avec résistance, soit avec tolérance. Cette recherche se propose d'établir une systématisation des réactions des chefs religieux par rapport à quelques symboles de la science moderne.

Mots-ClÉs: Science et religion. Religions dans le "Recôncavo" de Bahia/ Brésil. Perceptions de la science par les chefs religieux.

Amilcar Baiardi - Doutor em Ciências Humanas. Professor titular aposentado da Universidade Federal do Recôncavo da Bahia, atuando também como professor permanente do programa de pós-graduação em Ensino, Filosofia e História da Ciência, da UFBA e da Universidade Estadual de Feira de Santana. Professor orientador da Universitat de Barcelona e da Università di Bologna. Membro da Academia de Ciências da Bahia. Nas grandes áreas de Ciências Sociais Aplicadas e Ciências Humanas, tem como interesse de pesquisa e ensino, História da Ciência, Políticas Públicas de Ciência e Tecnologia, Desenvolvimento Sustentável, Capital Social e Valores para a Cooperação. Publicações recentes: Os desequilíbrios regionais no Brasil e o papel do Estado. Bahia Analise \& Dados, v. 23, p. 653-669, 2013; Abordagens historiográficas aplicadas ao estudo das reflexões entre ciência e religião: Tese do Conflito, Tese do Yates e Tese da Complexidade. Hermeneutica, v. 13, p. 59-67, 2013; História da pesquisa e desenvolvimento, P\&D, na Bahia: vicissitudes e conquistas. Revista Brasileira de Inovação, v. 11, p. 219-232, 2012.

Fabihana Souza Mendes - Doutoranda em Difusão do Conhecimento pela UFBA. Professora da Faculdade Anísio Teixeira, em Feira de Santana-BA, nos cursos de Administração e Ciências Contábeis. Publicações recentes: Desequilibrios regionais, entraves ao desenvolvimento econômico e social do Nordeste pesquisa tecnológica. Bahia Analises \& dados, Salvador, p. 653-670; Mudanças técnicas, sociais e econômicas na avicultura do recôncavo da Bahia: análise dos avicultores integrados à avícola São João LTDA 'em prelo'. In: $51^{\circ}$ Congresso da SOBER - Sociedade de Economia, Administração e Sociologia Rural, 2013, Belém.

Wellington Gil Rodrigues - Doutorando no Programa de Pós Graduação em Ensino, Filosofia e História das Ciências da Universidade Federal da Bahia. Professor da Faculdade Adventista da Bahia. Têm experiência na área de Educação, com ênfase em História e Filosofia da Educação, Metodologia Científica, Fundamentos Teóricos Metodológicos para o Ensino de Ciências e Ciência e Religião. Publicações recentes: Abordagens historiográficas aplicadas ao estudo das relações entre ciência e religião: tese do conflito, tese Yates e tese da complexidade. Hermeneutica, v. 13, p. 59-67, 2013; O que o caso Galileu tem a ensinar sobre as relações entre ciência e religião?. Hermenêutica, v. 12, p. 113-117, 2012; Relações entre ciência e religião na perspectiva dos professores da Faculdade Adventista de Fisioterapia (FAFIS). Práxis Teológica, v. 1, p. 105-129, 2011. 